\title{
Auschwitz as the Sinthome of Modernity: A Žižekian Reading of Harold Pinter's Ashes to Ashes
}

\author{
Elias Naqipour (Corresponding Author) \\ Faculty of Humanities, Department of English Literature \\ Shahid Beheshti University, Tehran, Iran \\ E-mail: El.naqipour@gmail.com
}

Received: 29-03-2014

Accepted: 08-05-2014

Published: 01-09-2014

doi:10.7575/aiac.ijalel.v.3n.5p.112

URL: http://dx.doi.org/10.7575/aiac.ijalel.v.3n.5p.112

\begin{abstract}
This study attempts to show how Harold Pinter's literary agenda turned towards radical political intervention during the last period of his literary and political activism. In order to do this, Slavoj Žižek's rereading of F. W. J. Von Schelling, the German Idealist philosopher, in light of the Lacanian psychoanalytic concept of sinthome will be used in order to show how Harold Pinter opted for a radical politics of negativity in Ashes to Ashes as embodied in Rebecca's ultimate identification with the sinthome of the modern era.
\end{abstract}

Keywords: Slavoj Žižek, Harold Pinter, Contraction, Expansion, Sinthome

\section{Research Methods}

\subsection{The Contraction and Expansion of the Subject}

As Slavoj Žižek makes it clear, his whole philosophical project is to revive the philosophical legacy of German Idealism which has recently passed into oblivion through reading it in light of the Lacanian psychoanalysis: "the core of my entire work is the endeavour to use Lacan as the privileged intellectual tool to reactualise German Idealism" (Pound, 2008, p.27). What Žižek's argument regarding German Idealism and the Lacanian psychoanalysis implies is that the roots of Lacanian theories of subjectivity could be traced back to German Idealism with a specific interest on Friedrich Schelling's philosophy of subjectivity. Schelling's main emphasis, as Žižek understands it, concerns the existence of God and how He gave rise to the phenomenal world as it is perceived by the subject; or as Žižek states apropos of Schelling's philosophy, its central tenet is the problem of the beginning, of how the world as we know it came into existence in first place (1996, p.13), what is God's status in relation to the World? Where does he stand? What does he give to the world? These are the question the answers to which are provided, according to Žižek, by Schelling and, after him, by Lacan.

The central conflict in the problematic of God's creation is the one between pure potentiality and how this potentiality is actualised. According to Žižek's understanding of Schelling, before God gives birth to the world, He is pure potentiality and, therefore, enjoys 'Absolute Freedom'. However, in order to create the world, God has to make a decision, that is, He needs to extract Itself from pure potentiality and give substance to the world. God's act of creation needs to be understood in light of two of Schelling's terms, namely 'contraction' and 'expansion'. Before God makes His decision to create, He resides in "the chaotic-psychotic universe of blind drives, their rotary motion, their undifferentiated pulsating" (ibid. 13). In order to remove Himself from this lawless, chaotic situation God needs to contract Himself into the negativity of pure potentiality of a Will which paradoxically "opposes itself to itself in the guise of its own inherent counter-pole, the Will which wants something, that is the positive Will to expansion" (ibid. 23). In other words, God is stuck between two opposing Wills: the Will to negativity (contraction) and the will to create, to actualise (expansion). The paradoxical nature of the two wills, however, is resolved on a higher plain. As Marcus Pound explicates this paradox, "for God to create the world he first had to create nothing. In other words, God had to create first "a vacated space" for creation itself to subsequently fill" (28). It is clear now that this void of nothingness is related to God's contraction, that is, His self-willed withdrawal into the universe of blind drives. The next step in the story of creation is expansion. The act of expansion directly concerns the creation of something out of nothing, that is, it is the act of expansion which inaugurates the phenomenal existence. One need not go far to see the religious origins behind God's expansion; Saint John's Gospel begins with the following: In the beginning was the Word. Saint John's Word exists in order to expand, that is, to signify the primary chaotic rotary motion of the drive. Rex Butler in Slavoj Žižek (2005) renders the relation between contraction and expansion in his best way as follows: 'Contraction', that moment when the free, untethered will actualizes itself in the guise of a will that wills 'nothing', is equivalent to that first 're-marking' of the void, the primordial division of a thing from itself. 'Expansion' is the moment of the naming of this 'nothing', of having something stand for it (81). In this way the true meaning behind Schelling's thesis that "the true beginning is not at the beginning" (Žižek, 1996, p. 1) takes on a new meaning. Saint John's "In the beginning was the Word" is not properly at the beginning; before the beginning was the contraction of chaotic pulsating of the drive. 
The affinities between Žižek's reading of Schelling and of Descartes, as the legitimate precursor to Schelling, are striking. Descartes, in the same fashion, in order to establish the contours of modern knowledge, by means of his radical 'methodical doubt', first contracts himself into the abyss of cogito and then expands himself to establish a new knowledge, that is, Descartes names the void of contraction. One could even locate a true precursor to both Lacan and Žižek at this point. In terms of Lacanian psychoanalysis, it is the Symbolic Order proper that names the void of the Real which both precedes and comes after the Symbolic. Suffice it to recall the Lacanian thesis that "the letter kills" that which was before it. As Žižek makes it clear

The ontological necessity of "madness" resides in the fact that it is not possible to pass directly from the "animal soul" immersed in its natural life-world to "normal" subjectivity dwelling in its symbolic universe. The vanishing mediator between the two is the "mad" gesture of radical withdrawal from reality that opens up the space for its symbolic (re)constitution. (1999, p. 35).

The crucial aspect of contraction and expansion is the intermediary role of "decision", that is, the subject, in order to expand, to name, the chaotic pulsating of the drive, has to take full responsibility of his decision to change the coordinates of the present Symbolic Order in order to replace with a new one. The far-reaching political implication of this is that founding a new form of subjectivity requires that the subject contracts itself, that is, to annihilate all the connections with the symbolic texture in order to further expand a new Symbolic Order while at the same time he takes full responsibility for his actions. The subject must abide by his decision and take no heed of its possible consequences.

There is no doubt that Žižek's engagement with Schelling is purely on the formal level. In other words, Žižek is not concerned whatsoever with the fact whether the Christian or the Jewish God exists or not; what is of prime importance for Žižek is the God-like status of the Lacanian subject. Based on what Žižek believes, the subject, like Schelling's God, was in a state of complete potentiality before it gained its subjectivity. Put differently, the subject, prior to its entry into the Symbolic Order, enjoys the "Absolute Freedom" of the rotary motion of the drives. To be subject in the first place, the one has to freely choose its subjection in language. For Žižek an authentic subject emerges the moment he decides to withdraw into the indeterminate "night of the world", that is, after eradicating all the connections with the Symbolic Order. It is only after the primal move of contraction that the subject as such emerges.

As it was earlier argued, the subject needs to make a decision before it expands itself in order to name the void of contraction. This decision is, according to Žižek, accompanied by a certain faith in the act itself, that is, the withdrawal into the 'madness' of the drives needs a complete trust in the cause which demands from the subject to abandon even what is most dear to him, namely his life. In order to explain this, Žižek makes a shrewd recourse to the story of Abraham in Bible. Briefly put, Abraham was ordered by God to sacrifice his son, Isaac, for the sake of God. Abraham, despite the seemingly unethical call from God to murder his own son, remained faithful towards God and proceeded to carry out what God has demanded from him. What makes Abraham great, therefore, "is not his moral stature, nor the moral interpretation of his action, but his fidelity to God's word. Abraham remained unflinching in his faith in God against the reason that judged this act murderous" (Pound, 2008, p. 34). What is at stake in the subject's unflinching faith to contraction (to withdrawal-into-self), therefore, is that first he has to "renounce the particular 'aesthetic' content for the sake of the universal ethical Law; then, Faith compels us to suspend this Law itself" (Žižek, 1996, p.121). Marcuse Pound's interpretation of the Žižekian Faith is that the true subject is "someone who is resigned to give up everything: familiar ties, family duties, love, and ultimately the self; adopting the standpoint of someone absolutely resigned to loss" $(2008,35)$. In terms of politics, however, Žižek's revival and utilisation of Schelling's philosophy serves only one purpose: to bring to the fore that for any political change to happen, there has to be a radical break with existing symbolic framework. This is achievable with the proviso that the subject embraces the ethical universal attitude of severing all ties with the existing Symbolic Order. The next step is to build a new one.

\subsection{Identification with the Sinthome as the Final Phase of Psychoanalytic Treatment}

One of the most important contributions Lacan made to the field of psychoanalysis is to introduce the notion of foreclosure. Simply put, "there is a certain foreclosure proper to the order of signifier as such; whenever we have a symbolic structure it is structured around a certain void, it implies the foreclosure of a certain key signifier" (Žižek, 1989, p. 78). What this means is that in every act of symbolisation, in every act "naming", a certain surplus remains as a leftover of the process of signification. For instance, in order for the signifier of Man to exist, the signifier of the primordial Father of the Freudian Totem and Taboo has to be repressed into the unconscious of the subject; this foreclosure "proper to the order of the signifier" guarantees the conditions of possibility of Man as such to exist. One can easily draw the obvious conclusion that every symbolic being, every symbolic entity, has at least one key signifier foreclosed in order to exist. With respect to Schelling, it is God's ground, that is, His place of the "chaotic-psychotic universe of blind drives", that, when expanded, is foreclosed so that the symbolic phenomenal world may come into existence.

Lacan's name for the foreclosed element is symptom. For the early Lacan, symptom takes the form a signifier. According to Žižek, "At the beginning, in the early 1950s, a symptom was conceived as a symbolic, signifying formation, as a kind of cypher, a coded message addressed to the big Other which later was supposed to confer on it its true meaning" (ibid. 49). What Žižek implies is that the symptom is that foreclosed element which is transferred to the big Other who is supposed to decipher its meaning and thereby dissolve it for the subject. According to Žižek

Symptom can not only be interpreted but is, so to speak, already formed with an eye to its interpretation: it is addressed to the big Other presumed to contain its meaning. In other words, there 
is no symptom without its addressee: in the psychoanalytic cure the symptom is always addressed to the analyst, it is an appeal to him to deliver its hidden meaning. (ibid. 79)

The problem with this definition of symptom is that when it is addressed to the big Other there begins a transferential relation between the subject and the big Other. The subject presupposes that the big Other is in possession of a certain answer to his symptom and therefore the big Other is perceived to be "consistent, complete, because its very formation is an appeal to the Other which contains its meaning" (ibid. 89). The common perception of symptom in the psychoanalytic circles was that once it is deciphered it no longer exists. The obvious counter-argument here is that if symptom is the foreclosed element which guarantees the reality - reality here does not mean the Lacanian Real but the Symbolic - of the individual, then once it is dissolved the subject dissolves with it. Accordingly, Lacan changed his perception of symptom and supplanted it with his neologism sinthome. The difference between symptom and sinthome is that the latter is immune to interpretation and therefore does not dissolve; sinthome persists in the Real and even if the subject becomes familiar with his symptom after deciphering, it still persists. The reason Lacan, and following him Žižek, provides to account for the persistence of sinthome is that it is "permeated with idiotic enjoyment. Le sinthome is not the symptom, the coded message to be deciphered by interpretation, but the meaningless letter that immediately procures jouis-sense, "enjoyment-in-meaning"' (Žižek, 1991, pp. 128-129). The fact that sinthome is permeated with enjoyment leads to the obvious conclusion that it is the enjoyment that is the ultimate support of the individual.

The crucial fact about sinthome is that it exists both within and without the subject. Thus the Lacanian notion of exsistence "as the impossible-real kernel resisting symbolisation.... It is, of course, this ex-sistence of the real, of the Thing embodying impossible enjoyment, that is excluded by the very advent of the symbolic order" (ibid. 137). If the difference between sinthome and symptom is that the former is loaded with jouissance, then it can never be integrated into the Symbolic Order: it can only be recognised as such. It is based on this fact that Žižek believes that sinthome is the "non-analysable obstacle". According to Žižek,

If the symptom is a formation of the unconscious to be dissolved through interpretation, the sinthome is the "indivisible remainder" which resists interpretation and interpretive dissolution, a minimal figure or node which condenses the subject's unique mode of enjoyment. (2012, p. 967).

It is as a result of sinthome's resistance to be interpreted which compels both Lacan Žižek to conclude that sinthome is not addressed to be big Other and therefore there no answer for that reserved somewhere. That is why Žižek, following Lacan, declares that "the end of the psychoanalytic process is identification with the symptom. The analysis achieves its end when the patient is able to recognize, in the Real of his symptom, the only support of his being" (Žižek, 1989, p. 81). Identification with the symptom is concomitant with bringing to light the phantasmatic structure of ideology since the symbolic framework of ideology is sustained on the condition that this ex-timate kernel is excluded; once it is identified with the veil of fantasy torn away.

The issue of identification with the sinthome brings to the forth once again the Schellingian God-like status of the subject who must contract itself in order to identify with that ex-timate kernel. It is the direct, unmediated contactidentification with sinthome which occasions the existence of the true Lacanian subject. Identification with sinthome is followed in the next step by expansion which is tantamount to giving shape to another phantasmatic structure. The difference between the second mode of phantasmatic structure with the one prior to the contraction of the identification with the sinthome is that the former is constructed based on what Žižek following Alain Badiou calls Truth-Event. Accordingly, "Truth is contingent; it hinges on a concrete historical situation; it is the truth of this situation, but in every concrete and contingent historical situation there is one and only one Truth which, once articulated, spoken out, functions as the index of itself and of the falsity of the field subverted by it” (Žižek, 1999, p. 131).

\section{Application}

\subsection{Auschwitz as Sinthome}

More than half a century ago Theodor Adorno declared that "to write poetry after Auschwitz is barbaric". Although Adorno's commentary on Literature after Auschwitz was limited to lyric poetry, one can extend its application to other domains of Literature as well. The basis of Adorno and his colleague's argument against Literature after Auschwitz is based on the fact that Literature on Auschwitz tends to fall into two extremes. As Emily Budick (1996) explains "To survivors and nonsurvivors alike, the Holocaust has always seemed to be beyond our ability to know it and therefore to represent it. Writing about the Holocaust has seemed not simply to miss it but to violate it: to distort or trivialize or even to deny it" (329). But this caution wrought with an aura of mystification of Auschwitz and Holocaust did not prove to be robust enough to prevent writes as diverse as Maurice Blanchot, Primo Levi, Imre Kertész, Anne Frank, and, most importantly, Harold Pinter from writing about it. With respect to Pinter, he endeavoured to skirt being engaged in trivialising atrocities perpetrated in Auschwitz by basing his account of those atrocities in Ashes to Ashe on Gitta Sereny's biographical account in Albert Speer: His Battle With Truth.

As one of the most political plays by Harold Pinter, Ashes to Ashes is about Rebecca's experiences of brutality during World War II in concentration camps in Nazi Germany. The play opens with Devlin, Rebecca's lover, standing beside her while she is recounting her past encounter with a possible torturer:

Well... for example... he would stand over me and clench his fist. And then he'd put his other hand on my neck and grip it and bring my head towards him. His fist... grazed my mouth. And he'd say, "Kiss my fist" (29). 
After she kisses the man's fist, she is subjected to brutal sexual harassment. Delving asks her to describe the appearance of the man who tortured her:

DEVLIN. Look. It would mean a great deal to me if you could define him more clearly.

REBECCA. Define him? What do you mean define him?

DEVLIN. Physically. I mean what did he actually look like?... Can't you give him a shape for me, a concrete shape? I want a concrete image of him, you see... an image I can carry about with me

REBBECA. I can't tell you what he looked like. (34-6).

Rebecca's inability to provide a thorough description for Devlin does not refer to the fact she has forgotten it, but that she is unwilling to do so:

DEVLIN. Have you forgotten?

REBECCA. No. I haven't forgotten. But that's not the point (36-37).

The reason she cannot describe is that the torture and atrocities that she has endured are so immense that any articulation of the incidents would coincide with its opposite, that is, it would, in the words of Budick, "distort or trivialise" it. However hard she tries to remember, she simply fails.

When she remembers that she has been tortured and even raped, she suddenly recollects that the man worked as a "guide" in some travel agency. Pinter's sagacity here in calling the man a "guide" will receive its full double meaning once the reader recognises the allusiveness of the word "guide". As Gene Plunka explains, "one translation of the German 'Führer,' besides 'leader,' is also 'guide,' which ironically may refer to his role in deportation or making 'travel' arrangements" (2009, pp. 321-322). This interpretation receives its full credit when later Rebecca says that she was once taken by the "guide" to some factory where labourers were doing the drudgery:

REBECCA. I think it had something to do with a travel agency. I think he was some kind of courier.... He had a lot of responsibility.... Did I ever tell you about that place?.... It was a kind of factory, I suppose.

DEVLIN. What do you mean, a kind of factory? Was it a factory or wasn't it? And if it was a factory, what kind of factory was it?

REBECCA. Well, they were making things - just like any other factory. But it wasn't the usual kind of factory. (39)

Rebecca's description of the factory which was "damp" and the workers "weren't dressed for the weather" brings to mind, according to Plunka, "The images of the gruesome working conditions" and the "slave labour camp that lacked sanitation facilities" (322). It is actually these memories which suddenly cause Rebecca to fall into a deliriously mad reverberation. She suddenly recollects that her torturer used to "go to the local railway station and walk down the platform and tear all the babies from the arms of their screaming mothers" (41). This image, as Michael Billington (1996)shows, comes from Pinter's reading of Gitta Sereny's book. Pinter says that "I've always been haunted by the image of the Nazis picking up babies on bayonet-spikes and throwing them out of windows" (375).

After all these, the connection between Ashes to Ashes and the Holocaust becomes even more palpable. However, one should not limit the implications of Ashes to Ashes just to include an historically specific event which took place in Germany during World War II. In recent philosophical debates Auschwitz is occupying the centre stage to the extent that it is associated with the modern age. Therefore, Holocaust and Auschwitz must be used as a paradigm; paradigm, of course, in the sense that Agamben uses it: "When I say 'paradigm' I mean something extremely specific - a methodological approach to problems, like Foucault's with the panopticon, where he took a concrete and real object but treated it not only as such but also as a paradigm so as to elucidate a larger historical context" (Durantaye, 2009, p. 218). When Agamben employs Auschwitz and concentration camps as paradigms of the modern age, Žižek has every right, then, to equate them "with a phenomenon that designates most accurately the 'perverse' obverse of twentiethcentury civilisation" (Žižek, 1989, p. 51). If Žižek's proposal is true, then it is the Holocaust and concentration camps that need to be repressed so that the ideological machinery of the Capitalism would continue to run smoothly. In other words, atrocities in Auschwitz are the sinthome of the twenty-century Capitalism.

There are indications in Ashes to Ashes which point towards the fact that Pinter treated Rebecca's memories of her traumatic experience in concentration camps as her sinthome which, insofar as it is repressed, allow her to continue with her normal life. However, once this sinthome is brought back into the lived experience of the subject then it becomes traumatic. The critical moment of the play is when after Rebecca remembers that her torturer was the same person who "tear all the babies from the arms of the screaming mother", she suddenly feels upset:

REBECCA. By the way, I'm terribly upset.

DEVLIN. Are you? Why?

REBECCA. Well, it's about that police siren we heard a couple of minutes ago. 
DEVLIN. What police siren?

REBECCA. Didn't you hear it? You must have heard it. Just a few couple of minutes. (42)

The sound of the siren corresponds perfectly with the Žižekian notion of "voice as object". According to Žižek, "voice as object" is "without a bearer, which cannot be attributed to any subject and thus hovers in some indefinite interspace. This voice is implacable precisely because it cannot be properly placed, being part neither of the diegetic "reality" nor of the sound accompaniment (commentary, musical score)" (1991, p. 126). Devlin tries to rationalise the inexplicable source of the sound and to assure Rebecca that it was the sound of police car which she heard. However, for Rebecca the sound of the siren brings with it a whole array of associations from the concentration camps that still haunt her imagination. Rebecca's feelings towards the origins of the sound are quite ambivalent; the sound makes her both insecure and the same time she does not want to lose it:

DEVLIN. Does that make you feel secure?

REBECCA. No! it makes me feel insecure! Terribly insecure.

DEVLIN. Why?

REBECCA. I hate it fading away. I hate it echoing away. I hate it leaving me. I hate losing it. I hate somebody else possessing it. I want it to mine, all the time. It's such a beautiful sound. (43)

The sound of siren as sinthome for Rebecca is so traumatic that she can neither afford to lose it nor to keep it. The sound as sinthome remains at a purely formal level. In other words, the sound has no body to locate its origin and that is why, as Devlin says, it will circulate around and will be heard again and again. The crucial fact at this point for Rebecca is that if the sound fades away she will lose her consistency and that is why she is so terribly upset about "losing it". As Žižek himself declared sinthome, that is, the sound of the siren redolent with previous memories of Auschwitz and concentration camps, "functions as the ultimate support of the subject's consistency, the point of 'thou art that,' the point of marking the dimension of 'what is in the subject more than himself' and what he therefore 'loves more than himself" (1991, p. 132). The important thing about the sound of the siren for Rebecca is that it is not a symptom - a coded message addressed to the big Other who is supposed to know its answer - that once recognised fades away.

Rebecca is perfectly aware of the fact that the Other does not have the response to her symptom, otherwise, after so many attempts at narrativising it, at integrating it into the Symbolic Order, it would simply disappear. Suffice it to recall what Žižek has to say apropos of the failure of the integration of the sinthome:

All the different attempts to attach this phenomenon to a concrete image ('Holocaust', 'Gulag'...), to reduce it to a product of a concrete social order (Fascism, Stalinism ... .) - what are they if not so many attempts to elude the fact that we are dealing here with the 'real' of our civilization which returns as the same traumatic kernel in all social systems? (1989, p. 51).

Rebecca's distrust of the big Other's ability to decipher the coded message of the symptom becomes apparent when she expresses her disappointment with God as the big Other:

DEVLIN. Have you noticed? I'm letting you slip. Or perhaps it's me who is slipping. It's dangerous. Do you notice? Do you notice? I'm in a quicksand.

REBECCA. Like God. (47)

Devlin, terrified at the suggestion of losing the fantasy framework of his symbolic construction which is the support of his reality, suddenly berates Rebecca for her distrust in the big Other:

God? God? You think God is sinking into a quicksand? That's what I would call a truly disgusting perception. Be careful how you talk about God. He's the only God we have. If you let him go... then what will you do? You know what it'll be like, such a vacuum?... Absence. Stalemate. Paralysis. A world without a winner. (47-8)

Devlin's statement that without the big Other the world would be without "a winner" perfectly exemplifies that he is fundamentally afraid of being divested of his phantasmatic construction which keeps the "vacuum" at bay for him.

It has to be acknowledged that at first Rebecca too was hesitant whether to embrace and identify with her symptom or not. After Devlin says that what right entitles her to talk about the atrocities she endured in the concentration camps, Rebecca simply dismisses her right to narrate the brutalities:

I have no such authority. Nothing has ever happened to me. Nothing has ever happened to me. Nothing has ever happened to any of my friends. I have never suffered. Nor have my friends. (48)

Rebecca's desperate attempt reflects at a larger scale the tendency of human subjects to ward off too much proximity with their symptoms. The most heinous experience for a human being is to confront the abyssal negativity; in other words, when the subject is faced with the lack of any support in the Symbolic Order he loses his subjectivity proper. One should not, however, be duped by the role Devlin plays with respect to Rebecca's trauma. Devlin should not be mistaken with the analyst in the Lacanian sense. Devlin is not the disinterested subject occupying the position of object petit $a$ who tries to make the subject face the nullity of his reaching desperately after the object-cause of desire. Devlin, on the contrary, plays the role of what Žižek, following Hegel, calls the "Beautiful Soul". The "Beautiful Soul" is "encountered at its purest in the negative experience of falsity and breakdown, when the subject assumes the position of a judge exempt from what he is passing a judgement on" (Butler, Laclau, Žižek, 2000, p. 228). It is exactly 
commensurate with Devlin's position; it later turns out that Devlin is also responsible for Rebecca's condition in the concentration camps when he assumes the role of the torturer from the Rebecca's story. Suffice it to recall the moment Devlin says that he would not be concerned with Rebecca's past since "Your past is not my business.... When you lead a life of scholarship you can't be bothered with the humorous realities, you know... Your mind is on other things" (50).

Ashes to Ashe gives the sense that everything happens twice. After her initial report about her being sexually abused and also her travel to the "damp" factory, Rebecca once again remembers the same atrocities which resemble a genocide perpetrated in the concentration camps. She recalls the moment when she was looking "of the window and into the garden" when the "guides... were ushering all those people across the beach. It was such a lovely day.... And I saw all these people walk into the sea. The tide covered them slowly" (52). In line with the issue of circularity is Rebecca's remembrance of the voice, this time hazily. She recalls that "I'd been dreaming... But in this dream a voice was calling" (54). This time Rebecca reacts differently to the voice. She overcomes her fear of losing the sound by totally identifying with it, by embracing the sound. She recounts the time when a man she "watched him walk down the platform and tear all the babies from the arms of their screaming mother" (55). The free floating sound is finally attached to the bodies of the screaming mothers. It turns out at the end that Rebecca was herself among those women whose children were torn from them at the platform.

The ending of Ashes to Ashes is very suggestive. In his initial stage directions to the play, Pinter writes that "the room darkens during the course of the play". Pinter continues to write "by the end of the play the room and the garden are only dimly defined." The stage direction needs to be analysed on purely formal level, that is, it must be interpreted in such a way which corresponds perfectly with Rebecca's final position of identification with the sinthome. At the end of the play, when Rebecca realises that there is no escaping the spectre of her sinthome, she decides to identify with it, to fully embrace it. According to Žižek, it is precisely the act of identification with the sinthome with guarantees the subject's freedom. In other words, insofar as Rebecca refuses to acknowledge the traumatic presence of the Nazi's atrocities, she remains haunted by their image. However, once she identifies with it, she has carried out the most darting action of all, that is, to fully assume the dimension of the repetitive movement of the death drive. Her final assuming of the repetitive movement of the drive is also echoed by the repetitive form of her speech in which whatever she says is echoed to her. Her identification with the sinthome which is identification with the inherent excluded barbarities of Capitalism is accompanied by the free act of assuming the pure negativity of the death drive. In the final analysis, there is a formal similarity between the diming of the lights at the end and Žižek's metaphor for the negativity of the death drive as the "night of the world".

\subsection{Rebecca as Pure Contraction}

The prerequisite to the act of identification with the sinthome as the final phase of analytic treatment is Schelling's contraction. As it became clear in the previous sections, for It to remove itself from the chaotic pulsating of the drive, God needs to contract Itself into pure potentiality. It is only after the act of contraction that God becomes able to give birth to the phenomenal world. There is, however, a paradox involved in here. God, in order to create, is stuck between the two opposing wills of contraction and expansion. On the one hand, God must create, must expand, in order to be in the first place. On the other hand, if God "names" the emptiness of the void of His negativity, it becomes alienated in His will of expansion. Rebecca's situation is no better than this. From the very beginning, she is hesitant whether to identify with the victims of Auschwitz or not. At times she even denies the atrocities.

The mediator between the indecision of the two contraries of contraction and expansion is the moment decision. The subject must decide to act. When the subject decides to act, he must assume full responsibility for the consequences of his decision to expand, to act. What is important about Rebecca is that she, in sharp contrast to Devlin who was himself the agent who carried out those brutalities in the concentration camps but refuses to acknowledge his complicity in the crimes, assumes full responsibility for her decision to act and to contract, that is, to remove herself from the care of the Symbolic Order and put herself into the abyss of negativity of the vortex of the drive.

It is only after she remembered the brutality with which people in the camps massacred in the sea that Rebecca decides to act, that is, to create a rupture between the previous Symbolic Order and the latter. Rebecca assumes full responsibility for the rupture regardless of its consequences:

Oh by the way somebody told me the other day that there's a condition known as mental elephantiasis... This mental elephantiasis means that when you spill an ounce of gravy, for example, it immediately expands and becomes a vast sea of gravy which surrounds you on all sides and you suffocate in a voluminous seas of gravy. It's terrible. But it's all your own fault, you brought it upon yourself, you are not the victim of it, you are the cause of it. (53)

Rebecca's attitude of accepting the responsibility for the rupture, that is, the contraction into pure negativity, stands in sharp contrast to Devlin's attitude that previously proved his "Beautiful Soul". When the subject of responsibility and duty is raised, Devlin's perverse attitude becomes apparent. Devlin describes himself as a man "who ducks his head and moves on through no matter what wind or weather who gets there in the end.... A man who doesn't give a shit. A man with a rigid sense of duty" (51). Devlin does not scruple to refuse to take responsibility of the unethically inhuman brutalities to which he subjected his victims in the concentration camps.

Rebecca finally realises that in order to change the existing order of things, that is, the order in which Capitalism needs to exclude and repress its traumatic underside - which is obviously the direct consequence of its ideological machinery - which amounts to nothing less than concentration camps of the twentieth-century, she needs to identify with 
Capitalism's sinthome. It is here that the insufficiency of the notion of symptom comes to the fore. If the concentration camps were nothing more than a coded message addressed to the big Other who would in turn dissolve it through deciphering it, then Rebecca's initial attempt at "verbalising" the traumatic kernel would succeed in erasing it. The fact is that even after all the attempts to integrate the trauma of concentrations camps into her psyche, she, nevertheless, fails. The only way open to her is to identify with the sinthome.

It must be mentioned that any act of identification with sinthome needs to be preceded by an act of contraction. As previously mentioned, the darkening of the room draws a perfect analogy between Rebecca's withdrawal-into-self and the final diming of lights. An important aspect of contraction is to "renounce the particular 'aesthetic' content" in order to make oneself ready for the abyssal of negativity. In line with this, Rebecca's final delirium in which she gives up her child in a bundle gains its full meaning. As Rebecca remembers, she was escaping from the camp while she covered her child in her shawl and "held it under my arm", the baby suddenly cries and attracts the attention of the guard who orders her to come back and takes her child away. Rebecca at this point renounces her "aesthetic content", that is, she renounces her pathology, her most precious possession, her child, and even renounces herself to be free. In other words, she adopts the position of "someone absolutely resigned to lose." In the final scene, Rebecca contracts herself, that is, she forsakes anything which is most dear to her in order to create, in a God-like manner, from the beginning. In other words, contraction is a prerequisite to the act of identification with sinthome. When sinthome is integrated into the Symbolic Order, Rebecca loses her Symbolic being and, therefore, she becomes free to choose since sinthome dissolves the very symbolic texture. It is her contraction, her withdrawal-into pure negativity which helps her lose her ties with the Symbolic Order. It is worth requoting Žižek apropos of Rebecca's condition:

The ontological necessity of "madness" resides in the fact that it is not possible to pass directly from the "animal soul" immersed in its natural life-world to "normal" subjectivity dwelling in its symbolic universe. The vanishing mediator between the two is the "mad" gesture of radical withdrawal from reality that opens up the space for its symbolic (re)constitution. (1999, p. 35).

The act of contraction is not, therefore, an end in itself, but it paves the way for a fresh start. Rebecca, therefore, as subject, resembles Schelling's God of creation who acts as a mediator between the "chaotic pulsating of drives" and the new ensuing order created out of the disorder of the drive.

\section{Conclusion}

In line with Giorgio Agamben's claim that the Nazi's concentration camps serve as the ultimate limit of the ideology of Capitalism and modernity itself, Ashes to Ashe is an attempt to bring into sharp relief the ultimate excluded sinthome of Capitalism. In order to break loose from the logic of Capitalism, one must put oneself in the position of identifying with the excluded part. According to Žižek, this cannot be achieved unless the subject assumes the God-like status of creation. In order to do this Žižek does not

[...] resort to the typical leftist strategy of simply undermining or subverting order. Instead, Žižek investigates the question of how order first emerges from disorder. What split or alienation within subjectivity allows the hegemonic ideological order to maintain itself? Žižek develops the psychoanalytic insight that the unconscious figure of the father is a falsification: the version of the father figure (e.g., God, or the capitalist Master) that informs our unconscious behaviors is a pèreversion, an imposter. (Wood,2012, p.119).

What Pinter achieved in Ashes to Ashes, therefore, is very close to Žižek's philosophical edifice. Pinter's concern with the heinous conditions of Jews in concentration camps in Nazi Germany compelled him to dramatise them in order to shake his audience out of their complacency that concentration camps are not limited to Germany but to the whole modern Western culture. For Pinter, as for Žižek and Agamben, concentration camps represent the whole culture under Capitalism. When in an interview Pinter was asked whether Ashes to Ashes is solely concerned with Nazism, he responded "No, I don't think so at all. It is about the images of Nazi Germany; I don't think anyone can ever get that out of their mind. The Holocaust is probably the worst thing that ever happened, because it was so calculated, deliberate and precise, and so fully documented by the people who actually did it" (Plunka, 2009, p. 321). Being haunted by those images, Pinter, and by extension Rebecca, decides to identify with them rather than forget them.

\section{References}

Billington, Michael. (1996). The life and work of harold pinter. London: Faber and Faber.

Budick, Emily Miller. (1998). Acknowledging the holocaust in contemporary american fiction and criticism. In Efraim Sicher (Ed.), Breaking crystal: writing and memory after auschwitz (pp. 329-343). Urbana: University of Illinois.

Butler, Judith. \& Ernesto Laclau. \& Slavoj Žižek. (2000). De capo senzo fine. Contingency, hegemony, and universality: contemporary dialogues on the left. (pp. 213-262).London: Verso.

Butler, Rex. (2005). Slavoj žižek: live theory. New York: Continuum.

Derantaye, Leland de la. (2009). Giorgio agamben: a critical introduction. Oxford: Oxford University Press.

Pinter, Harold. (2001). Ashes to ashes. London: Faber and Faber Limited.

Plunka, Gene A. (2009). Holocaust drama: the theater of atrocity. Cambridge: Cambridge University Press. 
Pound, Marcus. (2008). Žižek: a (very) critical introduction. Cambridge: Wm B. Eerdemans Publishing Co.

Wood, Kelsey. (2012). Žižek: a reader's guide. Oxford: Wiley-Blackwell.

Žižek, Slavoj. (1989). The sublime object of ideology. London: Verso.

Žižek, Slavoj. (1991). Looking awry: an introduction to jacques lacan through popular culture. London: The MIT Press.

Žižek, Slavoj. (1996). The indivisible remainder. London: Verso.

Žižek, Slavoj. (1999). The ticklish subject: the absent centre of political ontology. London: Verso.

Žižek, Slavoj. (2012). Less than nothing: hegel and the shadow of dialectical materialism. London: Verso. 